\title{
Corrigenda to Magali Roques (2019)
}

Corrigenda to M. Roques, "Metaphor and mental language in late-medieval nominalism," in: Bochumer Philosophisches Jahrbuch für Antike und Mittelalter 22, 2019, 136-166. DOI: https://doi.org/10.1075/bpjam.00043.roq

See also the Editorial Notice in BPJAM 23 (2020).

[https://doi.org/10.1075/bpjam.00068.edi]

Page 136

On the philosophical level, this view suggests that theories of metaphor are linked to theoretical frameworks that aim at describing the underlying nature of language, thought, and communication.*

* See R. W. GibBs, Jr., "Metaphor of Thought. The State of the Art", in: R. W. Gibbs, Jr. (ed.), The Cambridge Handbook of Metaphor and Thought, Cambridge 2008, 3-13, 4 col.1.

Page 138

Late medieval grammarians and logicians debated the question whether the meaning of a term depends on intrinsic linguistic properties (de virtute sermonis) or whether it also depends on its ordinary usage (usus) or even on the intention of the speaker.*

* For a recent overview, see e.g. C. Dutilh Novaes, Formalizing Medieval Logical Theories: Suppositio, Consequentiae and Obligationes, Dordrecht 2007, 20-21.

Page 139

Note 7: For a survey and a bibliography, see I. Rosier-CATACH, "Grammar", in: R. Pasnau (ed.), The Cambridge History of Medieval Philosophy, Cambridge 2010, 197-207* * ead., "Speech Act and Intentional Meaning in the Medieval Philosophy of Language", in: Bulletin de Philosophie Médiévale 52 (2010): 55-80, 56-57.

Page 139

Note 8: transcription* in M. SIRRIDGE, "Robert Kilwardby: Figurative Constructions and the Limits of Grammar", in: G. Bursill-Hall/L. Geoffrey/S. Ebbesen/E. F. Koerner (eds.), De ortu grammaticae, Amsterdam/Philadelphia 1990, 321-337, at 322.

* and translation

Page 140

A close connection between ambiguity and metaphor is established on the basis of Aristotle's description of the so-called second mode of equivocation. In the Sophistical Refutations, Aristotle identifies thirteen types of fallacies (or incorrect arguments). According to Aristotle, six of these fallacies occur in language and seven are independent of language. Two of the fallacies that occur in language are of interest to us: those 
that arise because of lexical ambiguity (equivocation) and those that arise because of propositional ambiguity (amphiboly).*

* See especially G. SinkLer, "Ockham and Ambiguity", in: Medieval Philosophy and Theology 4 (1994): 142-164, 142; S. EвBESEN, "The Way Fallacies were treated in medieval logic", in: Cahiers de l'Institut du Moyen. Age Grec et Latin 55 (1987), 108, 113; S. Ebbesen, "Is "canis currit" ungrammatical? Grammar in Elenchi commentaries", in: Historiographia Linguistica $7.1 / 2(1980) 54$.

Page 140

As far as terminology is concerned, Ashworth explains, medieval grammar and logic handbooks use "the term 'equivocation' to cover both the case of homonymy (two or more words having the same pronunciation [...]) and polysemy (one word having two or more senses)."*

* E. J. Ashworth, "Equivocation and Analogy in Fourteenth Century Logic: Ockham, Burley and Buridan", in: B. Mojsisch, O. Pluta (eds.), Historia Philosophiae Medii Aevi: Studien zur Geschichte der Philosophie des Mittelalters, Vol. 1, Amsterdam 1992, 23-43, 26-27.

\section{Page 140}

Metaphorical discourse is a kind of expression which is deliberately equivocal. In the medieval tradition of logic and grammar, sometimes the term "metaphor" (translatio or transsumptio) refers to a specific figure of speech, based on a comparison, sometimes it refers to any kind of semantic transfer.*

* For a recent presentation of this question, see E. J. Ashworth, "Analogy and Metaphor from Thomas Aquinas to Duns Scotus and Walter Burley", in: Ch. Bolyard, R. Keele (eds.), Later Medieval Metaphysics: Ontology, Language, and Logic, New York 2013, 223-248, 226.

\section{Page 140}

Note 12: For references, see J. E. Ashworth, "Analogy, Univocation and Equivocation in some Early Fourteenth-century Authors", in: J. Marenbon (ed.), Aristotle in Britain in the Middle Ages (Rencontres de philosophie médiévale V), Turnhout 1996, 233-247, at $234-236$. $^{*}$

* See also R. van DER LeCQ, "Logic and Theories of Meaning in the Late 13th and Early 14th Century including the Modistae", in: D. M. Gabbay, J. Woods (eds.), Handbook of the History of Logic. Volume 2: Mediaeval and Renaissance Logic, Amsterdam 2008, 347-388, 366.

Page 140

Note 13: Aristotle gives his standard definition of metaphor in ARIST. Po. 1457b7-18. For more on this subject, see J. E. Ashworth, "Metaphor and the Logicians from Aristotle to Cajetan", in: Vivarium 45 (2007), 311-327, at 312.

Page 140-141

This means, following Sheehan, "as Paul Ricoeur explains, that metaphor is an act of deviation, borrowing, or substitution from literal language. ${ }^{15}$ In the Poetics, Aristotle suggests that a metaphor causes the hearer to create a 'non-native' meaning for a phrase by transferring, through a process of substitution or comparison, the meaning of one concept into a context that is typically inhabited by another concept.”*

* R. D. Johnson Sheehan, "Metaphor as Hermeneutic", in: Rhetoric Society Quarterly 29, no. 2 (1999): 47-64, 50. 


\section{Page 141}

For instance, as Jenny Ashworth explains, Peter of Spain, an authoritative thirteenth-century Parisian logician, "claims that transferred meaning (transsumptio) can be reduced to the second mode of equivocation," i. e. lexical ambiguity. When we say that fields laugh, he claims, there is a transfer of the initial sense of "laugh," fixed by an agreement in the community of the speakers (impositio) to the fields through custom (assuetudo). ${ }^{17}$ Similarly, Jenny Ashworth goes on, in the logic handbook written by William of Sherwood, another authoritative thirteenth-century English logician, "the second mode of equivocation is said to involve only improper or transumptive signification [...]"*

* E. Jennifer Ashworth, "Suárez on the Analogy of Being: Some Historical Background", in: Vivarium 33, no. 1 (1995): 50-75, 62.

Page 141

When it refers to a figure of speech, therefore, medieval logicians and grammarians give a definition of metaphor that is close to the one given by the Oxford English Dictionary: "the figure of speech in which a name or descriptive phrase is transferred to some object different from, but analogous to, that to which it is properly applicable". ${ }^{20}$ Thus, if I say "Ockham wanted to be a star", I mean that Ockham wanted to set himself apart from his fellow theologians, just as stars stand out in the sky. Max Black calls this "a substitution metaphor" because it is possible to replace it with a literal phrase with the same meaning. ${ }^{21}$ Metaphors such as these are taken to be purely verbal, i. e. without any cognitive value.*

* See D. L. Thompson, "Overcoming Our Childhood: Metaphors and the History of

Philosophy”, 1-9 (http://www.ucs.mun.ca/ davidt/OvercomingOurChildhood.pdf), 2.

\section{Page 141}

Note 19: Jenny Ashworth reminds us that "at the beginning, the notion of translatio was part of the theory of tropes, itself of Stoic origin."*

${ }^{*}$ E. J. Ashworth, "Analogy and Metaphor from Thomas Aquinas to Duns Scotus and Walter Burley”, in: Ch. Bolyard, R. Keele (eds.), Later Medieval Metaphysics: Ontology, Language, and Logic, New York 2013, 223-248, 226.

\section{Page 141}

Note 20: rectificatum, (QUINT. Inst., 8.6.4-18)

\section{Page 142}

Note 25: See also R. VAN DER LECQ, "Logic and Theories of Meaning in the Late 13th and Early 14th Century including the Modistae," in: D. M. Gabbay, J. Woods (eds.), Handbook of the History of Logic. Volume 2: Mediaeval and Renaissance Logic, Amsterdam 2008, 347-388, 351.

\section{Page 142}

Note 23: See e.g. E. J. Ashworth, "Signification and Modes of Signifying in Thirteenth-Century Logic: A Preface to Aquinas on Analogy", in: Medieval Philosophy and Theology (1991), 39-67, 43-44. 


\section{Page 142}

Note 28: See also E. J. AshworTH, "Signification and Modes of Signifying in ThirteenthCentury Logic: A Preface to Aquinas on Analogy", in: Medieval Philosophy and Theology (1991), 39-67, 45 .

\section{Page 147}

The danger is not metaphor itself, but unrecognized metaphor.*

* See D. L. Thompson, "Overcoming Our Childhood: Metaphors and the History of Philosophy”, 1-9 (http://www.ucs.mun.ca/ davidt/OvercomingOurChildhood.pdf), 8.

Page 148

Note 59: For a commentary on these texts, see e.g. S. Schierbaum, Ockham's Assumption of Mental Speech: Thinking in a World of Particulars, Leiden 2014, 65.

\section{Page 148}

Note 65: C. Panaccio, Le Discours Intérieur. De Platon à Guillaume d'Ockham, Paris 1999, 53, Engl. transl. J. Zupko, John Buridan: Portrait of a Fourteenth-Century Arts Master, Notre Dame 2003, 15, note 43.

\section{Page 152}

Thus, Ockham seems to think that it is not always possible to provide a paraphrase for metaphorical expressions, since sometimes the will of the speaker remains unknown.*

* See W. Grey, "Metaphor and Meaning", in: Minerva - An Internet Journal of Philosophy 4 (2000) (http://www.minerva.mic.ul.ie/vol4/metaphor.html), 4.

\section{Page 153}

There has been a long-standing debate whether metaphor can be explained in terms of simile. According to William Grey, the standard objection to this proposal is that "likeness or similarity is too weak a relation to explain any effective figure of speech. Everything is similar in some respect to everything else. [...] We need to specify likeness in some particular respect."*

* W. Grey, "Metaphor and Meaning", in: Minerva - An Internet Journal of Philosophy 4 (2000) (http://www.minerva.mic.ul.ie/vol4/metaphor.html).

\section{Page 153}

Marilyn McCord Adams explains that, "according to Ockham, one thing is a sign of another if there is a relation between them that renders the first apt to make the second known."*

* M. Mccord Adams, “Ockham's Theory of Natural Signification”, in: The Monist 61, no. 3 (1978), 444-459, 444.

\section{Page 155}

As highlighted by Hans Thijssen, "the interpretation of these documents has given rise to considerable scholarly controversy."

* J. M. M. H. Thijssen, "Once Again the Ockhamist Statutes of 1339 and 1340: Some New Perspectives”, in: Vivarium 28, no. 2 (1990), 136-167, 140. 


\section{Page 157}

Interpreters such as Hans Thijssen and Luca Bianchi view the statute as "a chapter in the history of hermeneutics." In particular, according to Thijssen, the four articles that we have presented illustrate a "clash between two hermeneutical programs." The question is "how we know which potential meanings should be attributed to an authoritative text."*

* J. M. M. H. Thijssen, "The Crisis over Ockhamist Hermeneutic and Its Semantic Background: The Methodological Significance of the Censure of December 29, 1340”, in: C. Marmo (ed.), Vestigia, Imagines, Verba: Semiotics and Logic in Medieval Theological Texts (XIIth-XIVth Century), Turnhout 1997, 371-392, 372.

Page 158

In the fourth part of the paper, I turn to John Buridan, who, to take over Frédéric Goubier's and Nausicaa Pouscoulous's words, "is viewed by some as the best candidate for the authorship of the statute.” ${ }^{\star}$

* F. Goubier and N. Pouscoulous, "Virtus sermonis and the Semantics-Pragmatics Distinction”, in: Vivarium 49, no. 1-3 (2011), 214-239, 226.

Page 158

Note 111: Buridan could be "a possible author of the statute,", although "he was no longer rector of the university in $1340 .{ }^{\text {”* }}$

* F. Goubier and N. Pouscoulous, "Virtus sermonis and the Semantics-Pragmatics

Distinction", in: Vivarium 49, no. 1-3 (2011), 214-239, 226, note 30.

\section{Page 158}

Note 112: For a commentary on these texts, see e.g. E. J. AshworTH, "Equivocation and Analogy in Fourteenth Century Logic: Ockham, Burley and Buridan", in: B. Mojsisch, O. Pluta (eds.), Historia Philosophiae Medii Aevi: Studien zur Geschichte der Philosophie des Mittelalters, Vol. 1, Amsterdam 1992, 23-43, 32-33.

\section{Page 160}

The theory according to which an equivocal term signifies its significates copulative or disiunctive has a long story. Thirteenth-century logicians thought that this analysis should not be accepted. ${ }^{127 \star}$

* See E. J. Ashworth, “ " Nulla propositio est distinguenda »: la notion d'equivocatio chez Albert de Saxe”, in: Joël Biard (ed.), Itinéraires d'Albert de Saxe, Paris-Vienne au XIVe siècle: Actes du Colloque organisé le 19-22 Juin 1990 dans le cadre des activités de l'URA 1085 du CNRS à l'occasion du 6ooe anniversaire de la mort d'Albert de Saxe, Paris 1991, 149-160, 156; Ebbesen, "Can Equivocation be Eliminated?".

\section{Page 161}

Note 132: For a recent commentary on this text, see e.g. C. Dutilh NovaEs, Formalizing Medieval Logical Theories: Suppositio, Consequentiae and Obligationes, Dordrecht 2007, 24.

Page 162

In other words, sentences always have an author and always are in relation to a subject (materia subjecta). ${ }^{136 *}$

* See F. Goubier and N. Pouscoulous, "Virtus sermonis and the Semantics-Pragmatics

Distinction”, in: Vivarium 49, no. 1-3 (2011), 214-239, 226. 


\section{Page 162}

Note 142: According to Catarina Dutilh Novaes, "the third mode of equivocation is the contextual mode of equivocation, and concerns terms that, taken individually, are not equivocal, but when put in a given propositional context, can stand for different things.”*

* C. Dutilh Novaes, “Theory of Supposition vs. Theory of Fallacies in Ockham”, in: Vivarium 45, no. 2 (2007), 343-359, 346.

\section{Page 163}

Thus, Frédéric Goubier and Nausicaa Pouscoulous explain, "to understand contextual re-impositions, we have to take into account original meanings." ${ }^{\star}$

* F. Goubier and N. Pouscoulous, "Virtus sermonis and the Semantics-Pragmatics Distinction", in: Vivarium 49, no. 1-3 (2011), 214-239, 235.

Page 164

"The history of philosophy is full of metaphors, analogies, and similes, from Plato's cave to Neoplatonic "emanation" to Rawls's "veil of ignorance"'”

* P. AdAmson, "All 20 "Rules for History of Philosophy", in: History of Philosophy Without Any Gaps, 31 December 2016 (https://historyofphilosophy.net/all-2o-rules-history-philosophy [Rule 13: Take metaphors seriously]).

\section{Page 164}

Medieval logicians and philosophers did not completely break with the traditional view of metaphor as a deviant use of a word or phrase, which is, according to Eva Kittay, "valued for its rhetorical force, but disdained for its ability" to conceal a fallacy.*

* E. F. Kittay, "Metaphor", (1996, reprinted) in: D. M. Borchert (ed.), Encyclopedia of Philosophy, 2nd Edition, Volume 6, Farmington Hills, MI 2006, 166-168, p. 166, col. 1.

\section{Page 165}

If Paul Ricoeur is right in saying that for Aristotle metaphor is nothing "more than a simple substitution of putting a [metaphorical] word in the place of a literal word which a comprehensive paraphrase would be capable of reconstituting in the same place", 156 then medieval logicians and philosophers were far from Aristotle in their views. ${ }^{*}$

* S. Driscoll, "Aristotle's A Priori Metaphor", in: Aporia 22, no. 1 (2012), 20-31, 24, English translation of P. Ricoeur, "La métaphore et le problème central de l'herméneutique", in: Revue Philosophique de Louvain 4. 70:5 (1972), 93-112, 101.

\section{Page 165}

Note 157: See also D. L. Thompson, "Overcoming Our Childhood: Metaphors and the History of Philosophy", 1-9

(http://www.ucs.mun.ca/ davidt/OvercomingOurChildhood.pdf), 2. 